\title{
Egg white-based strong hydrogel via ordered protein condensation
}

\author{
Tatsuya Nojima ${ }^{1,2}$ and Tomokazu Iyoda ${ }^{3}$
}

Despite the well-known thermal gelation property of egg white and its wide use in the food industry, the applications of gelled egg white in materials science are limited owing to the brittleness caused by the network structure of randomly associated denatured proteins. In this study, a gel material with high mechanical strength was fabricated from crude egg white proteins. Fluid materials containing orderly condensed proteins at regular intervals were prepared by addition of ionic surfactants to an egg white protein solution. The initiation of the heat denaturation of proteins from this ordered state with spatial confinement resulted in the formation of hydrogel materials with high mechanical strength. The maximum compressive fracture strength of the fabricated egg white-based hydrogel was $34.5 \mathrm{MPa}$, which is 150 -fold higher than that of gelled egg white prepared by boiling and comparable to that of strong chemically synthesized hydrogels. Chemical modification of sulfhydryl groups of proteins and treatment with a denaturant revealed that denatured polypeptide chains were covalently linked by disulfide bonds and noncovalently associated; these findings showed that the high mechanical strength of our material is due to the synergic effects of both covalent and non-covalent networks.

NPG Asia Materials (2018) 10, e460; doi:10.1038/am.2017.219; published online 5 January 2018

\section{INTRODUCTION}

The development of protein-based materials with excellent mechanical strength and functional properties is a major goal in materials science. Fibrous proteins, such as elastins, keratins, collagens, cotton silks and spider dragline silks, are widely used to create materials, ${ }^{1-3}$ whereas soluble globular proteins are less commonly used.

Hen egg is one of the most ubiquitous foodstuffs, and hen egg white (HEW) is a widely available protein resource. HEW contains more than 100 types of soluble proteins at high concentrations (100$110 \mathrm{mg} \mathrm{ml}^{-1}$ ). Thermal gelation of HEW is a well-known property with extensive applications in the food industry. However, HEW gels are not used to create advanced materials because of their weak mechanical strength. Gelled HEW is a type of hydrogel with a network structure constructed by aggregations of heat-denatured proteins. ${ }^{4}$ The protein aggregation is mediated by non-covalent interactions (hydrophobic interactions, electrostatic interactions and hydrogen bonds) and intermolecular disulfide cross-linking. ${ }^{5,6}$ Since the thermal denaturation and aggregation are random processes, the network structure of gelled HEW is not homogeneous. We assumed this inhomogeneity could explain the mechanical fragility of the HEW gel.

In the past decade, various types of chemically synthesized hydrogels with high mechanical strength have been reported. The homogeneity and order of the network structure of polymer chains are important factors determining the strength of gel materials. Tetra-PEG gel is a representative high-strength hydrogel with a homogeneous network structure. Sakai and coworkers reported that the combination of two types of four-arm macromonomers with end-linking groups that react with each other results in a homogeneous network. ${ }^{7,8}$ The structural monodispersity of proteins is advantageous for use as a macromonomer for the construction of the ordered network structure and for the creation of protein-based hydrogels with high mechanical strength. However, in contrast to the macromonomers of tetra-PEG gel, denatured proteins exhibit multimodal interactions at various regions. Therefore, protein denaturation and network formation need to start from a spatially confined situation with an ordered arrangement of proteins to prevent random aggregation.

Recently, we reported the surfactant-mediated ordered condensation of proteins and the formation of a high-protein-content fluid material referred to as a protein condensate (PC). ${ }^{9}$ The PC is a liquid phase separated from water that is prepared by the simple mixing of a protein solution and a combination of anionic and cationic surfactants $\left(\mathrm{C}_{x} \mathrm{E}_{y}\right)$. Both surfactants have a hydrophobic alkyl chain and a hydrophilic PEG chain. Ionic groups are positioned at the terminus of PEG. PC is generated by the assembly of the proteins surfactant complex, in which PEG chains are electrostatically bound to the protein surface while alkyl chains are located outside. Hydrophobic interactions between outer alkyl chains organize the complex to form the PC. Despite the clear phase separation from water, PC contains water retained by PEG chains. Proteins inside PC are in a water-rich environment, maintaining their native structure and function. Surfactants surrounding the protein prevent the direct contact of proteins, resulting in the packing of proteins at regular intervals in the PC.

${ }^{1}$ Institute of Innovative Research, Tokyo Institute of Technology, Kanagawa, Japan; ${ }^{2}$ State Key Laboratory of Bioelectronics, School of Biological Science and Medical Engineering, Southeast University, Nanjing, China and ${ }^{3}$ Harris Science Research Institute, Doshisha University, Kyoto, Japan

Correspondence: Dr T Nojima, State Key Laboratory of Bioelectronics, School of Biological Science and Medical Engineering, Southeast University, Nanjing 210096, China. E-mail: tatsuya.nojima@gmail.com

Received 2 September 2017; revised 13 October 2017; accepted 29 October 2017 
Various proteins can be used to form the PC by optimizing the ratio of anionic and cationic surfactants based on the electrostatic characteristics of the target protein.

Here we demonstrated the ionic surfactant-mediated ordered condensation of water-soluble HEW proteins and showed that heating of the condensed HEW protein resulted in the formation of a hydrogel with high mechanical strength.

\section{MATERIALS AND METHODS}

\section{Materials}

Homogenized and clear hen egg white protein solution was prepared by a previously reported procedure, with modifications. ${ }^{10} \mathrm{HEW}$ was collected from fresh eggs, filtered two times through a mesh net, diluted with an equal weight of water, stirred for $1 \mathrm{~h}$ at $4{ }^{\circ} \mathrm{C}$, and centrifuged $(10000 \mathrm{~g}$ for $20 \mathrm{~min})$. The supernatant was dialyzed using a $3500 \mathrm{MW}$ cutoff tube against water at $4{ }^{\circ} \mathrm{C}$ and centrifuged $(15000 \mathrm{~g}$ for $40 \mathrm{~min}$ ). The supernatant was collected and stored at $4{ }^{\circ} \mathrm{C}$. Protein concentration was determined by the BCA method (Pierce, Rockford, IL, USA) with bovine serum albumin as the standard.
Aqueous solutions $(100 \mathrm{mM})$ of anionic and cationic $\mathrm{C}_{x} \mathrm{E}_{y}(x=12, y=4.5$ and 9) were prepared as previously reported.9

\section{Preparation of protein condensates}

PC of HEW: To $1 \mathrm{ml}$ of $10 \mathrm{mg} \mathrm{ml}^{-1}$ HEW solution, 20 and $80 \mu \mathrm{l}$ of $100 \mathrm{mM}$ anionic and cationic surfactants $\left(\mathrm{C}_{12} \mathrm{E}_{9}\right.$ or $\left.\mathrm{C}_{12} \mathrm{E}_{4.5}\right)$ were added. The cloudy solution was centrifuged (10000 g for $1 \mathrm{~min}$ ) and $\mathrm{PC}\left(\mathrm{HEW}-\mathrm{C}_{12} \mathrm{E}_{9}\right)$ and $\mathrm{PC}$ (HEW $-\mathrm{C}_{12} \mathrm{E}_{4.5}$ ) were observed at the bottom of the tube as a pale-yellow transparent liquid. The procedure could be scaled up to prepare large quantities.

\section{Preparation of PC-Gel}

PCs were heated at $70{ }^{\circ} \mathrm{C}$ for $20 \mathrm{~min}$ on heat blocks or in a water bath. The PCgels were stored in water at $4{ }^{\circ} \mathrm{C}$.

\section{Water content measurement}

A thermogravimetric analysis was performed on a TG/DTA 6300 (Seiko Instruments Inc., Chiba, Japan) using $\sim 10 \mathrm{mg}$ of sample in air by increasing a

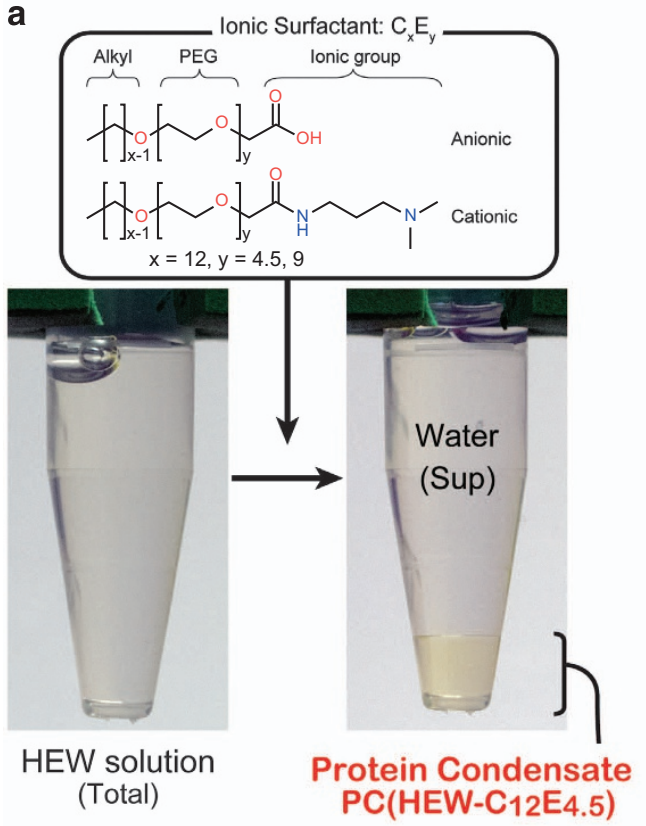

b

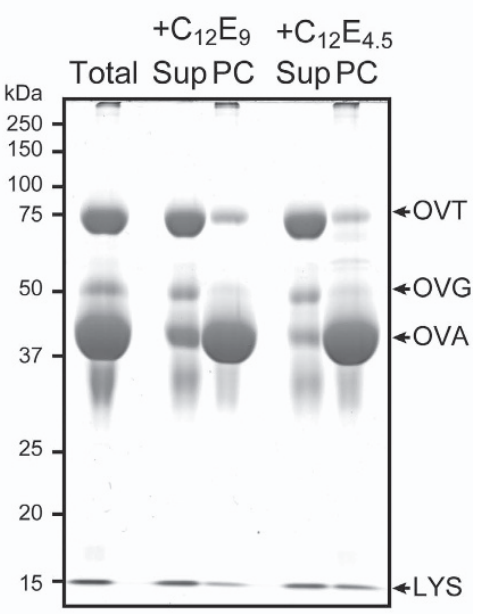

C

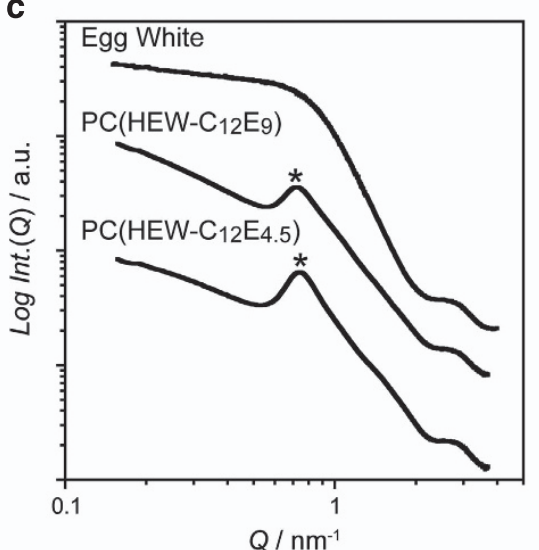

Figure 1 Formation of a PC from HEW protein. (a) The addition of an anionic and cationic surfactant to the HEW protein solution resulted in PC formation after centrifugation, observed as a pale-yellow fluid. (b) SDS-PAGE analysis of proteins in the PC and the supernatant (Sup). Total indicates total HEW proteins. Major proteins are indicated (OVT, ovotransferrin; OVG, ovoglobulin; OVA, ovalbumin; LYS, lysozyme). (c) SAXS profiles of egg white, PC (HEW $\left.-\mathrm{C}_{12} \mathrm{E}_{9}\right)$, and $\mathrm{PC}\left(\mathrm{HEW}-\mathrm{C}_{12} \mathrm{E}_{4.5}\right)$. PCs showed scattering peaks (asterisks). 
the temperature from 20 to $600{ }^{\circ} \mathrm{C}$ at a rate of $5^{\circ} \mathrm{C} \mathrm{min}^{-1}$. The water content was determined based on the weight loss up to $150^{\circ} \mathrm{C}$.

\section{Protein content measurement}

An aliquot of $100 \mu \mathrm{l}$ of PC(HEW) was mixed with $900 \mu \mathrm{l}$ of $20 \mathrm{mM}$ Tris-HCl buffer ( $\mathrm{pH}$ 8.0) containing $200 \mathrm{mM} \mathrm{NaCl}$. Under these salt conditions, PC (HEW) was converted back to aqueous solution; protein concentration was then determined by the BCA method (Pierce, Rockford, IL, USA) with bovine serum albumin as the standard.

\section{Small angle X-ray scattering (SAXS) measurement}

SAXS was performed using a NANOPIX with a two-dimensional detector and a CuKo X-ray with a wavelength of $\lambda=1.54 \AA$ (Rigaku Corp., Tokyo, Japan). Samples for SAXS experiments were mounted in a Kapton film cell (path length $1.1 \mathrm{~mm}$ ). An empty cell was used to determine background scattering. The scattering from the sample and background were measured for the same time period and normalized to the intensity of the transmitted beam.

\section{Mechanical strength measurements}

The compressive stress-strain measurements were performed using an INSTRON 5565 (Instron Corp., Norwood, MA, USA). The cylindrical gel sample with a diameter of $8.7 \mathrm{~mm}$ and thickness of $3.5 \mathrm{~mm}$ was compressed at a strain rate of $0.4 \mathrm{~mm} \mathrm{~min}^{-1}$. The compressive elastic modulus was independently measured using a SMT1-10N (Shimadzu Corp., Kyoto, Japan). The tensile stress-strain measurements were performed using an INSTRON 5943 (Instron Corp.). The dumbbell-shaped specimens with a length of $50 \mathrm{~mm}$, narrowest breadth of $5 \mathrm{~mm}$, and height of $1 \mathrm{~mm}$ were stretched at a strain rate of $5 \mathrm{~mm} \mathrm{~min}^{-1}$.

\section{RESULTS AND DISCUSSION}

In general, protein purification from biological samples is a costly process involving multiple steps and is disadvantageous for large-scale material production. Here we used unpurified crude HEW proteins for PC formation. The protein density of PC can be regulated by the chain length of the surfactant. In this study, we used two surfactant types with different PEG chain lengths, that is, $\mathrm{C}_{12} \mathrm{E}_{9}$ and $\mathrm{C}_{12} \mathrm{E}_{4.5}$. We added various ratios of anionic:cationic surfactants to the homogenized HEW solution and observed PC formation at a ratio of 20:80 in both $\mathrm{C}_{12} \mathrm{E}_{9}$ and $\mathrm{C}_{12} \mathrm{E}_{4.5}$ (Figure 1a). As in the case of purified proteins, after the addition of surfactants at the optimal ratio, the clear HEW solution became cloudy within a second. After centrifugation, the cloudy solution was clearly separated to an upper aqueous phase and lower PC. The obtained PCs were referred to as $\mathrm{PC}\left(\mathrm{HEW}-\mathrm{C}_{12} \mathrm{E}_{9}\right)$ and $\mathrm{PC}\left(\mathrm{HEW}-\mathrm{C}_{12} \mathrm{E}_{4.5}\right)$, individually, and $\mathrm{PC}(\mathrm{HEW})$, collectively. PC (HEW) was a transparent fluid that could be handled using a laboratory pipette. The protein contents of $\mathrm{PC}\left(\mathrm{HEW}-\mathrm{C}_{12} \mathrm{E}_{9}\right)$ and $\mathrm{PC}\left(\mathrm{HEW}-\mathrm{C}_{12} \mathrm{E}_{4.5}\right)$ were $124 \mathrm{mg} \mathrm{ml}^{-1}$ and $154 \mathrm{mg} \mathrm{ml}^{-1}$, respectively, similar to that of intact egg white $\left(100-110 \mathrm{mg} \mathrm{ml}^{-1}\right)$. PC(HEW $\left.\mathrm{C}_{12} \mathrm{E}_{9}\right)$ and $\mathrm{PC}\left(\mathrm{HEW}-\mathrm{C}_{12} \mathrm{E}_{4.5}\right)$ contained $80 \%$ and $76 \%(\mathrm{w} / \mathrm{w})$ water, respectively, based on a thermogravimetric analysis (Supplementary Figure S1).

The protein-based yields were $50 \%$ for $\mathrm{PC}\left(\mathrm{HEW}-\mathrm{C}_{12} \mathrm{E}_{9}\right)$ and $66 \%$ for $\mathrm{PC}\left(\mathrm{HEW}-\mathrm{C}_{12} \mathrm{E}_{4.5}\right)$, and approximately half of the proteins remained in the upper aqueous supernatant. Proteins contained in the PC and those remaining in the aqueous supernatant (Sup) were analyzed by SDS-PAGE (Figure 1b). An obvious difference in the protein components between the $\mathrm{PC}$ and Sup fraction was observed. $\mathrm{PC}\left(\mathrm{HEW}-\mathrm{C}_{12} \mathrm{E}_{9}\right)$ and $\mathrm{PC}\left(\mathrm{HEW}-\mathrm{C}_{12} \mathrm{E}_{4.5}\right)$ showed nearly identical components. $\mathrm{PC}(\mathrm{HEW})$ was mainly composed of OVA (ovalbumin). Small amounts of OVT (ovotransferrin) and LYS (lysozyme) were detected in the PC.

SAXS was used for the structural analysis of PC(HEW) (Figure 1c). PCs of purified proteins showed scattering peaks arising from the interference between constituent proteins, indicating the ordered arrangement of proteins at regular intervals. ${ }^{9}$ As in the case of purified proteins, $\mathrm{PC}(\mathrm{HEW})$ showed scattering peaks that were not observed in a

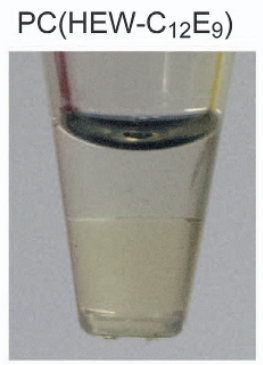

b

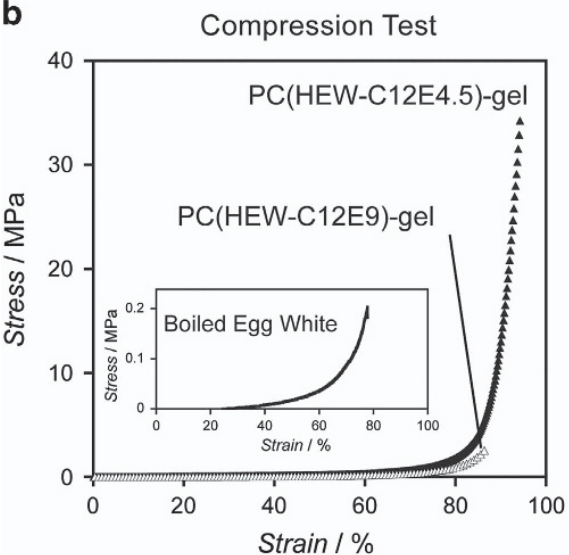

Gelled-PC(HEW- $\left.\mathrm{C}_{12} \mathrm{E}_{9}\right)$

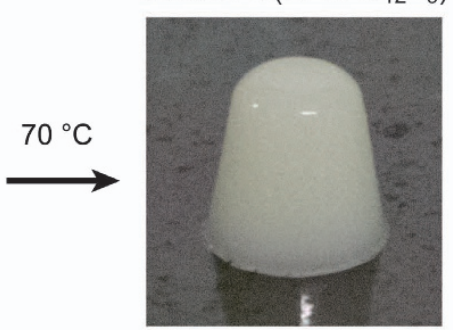

C

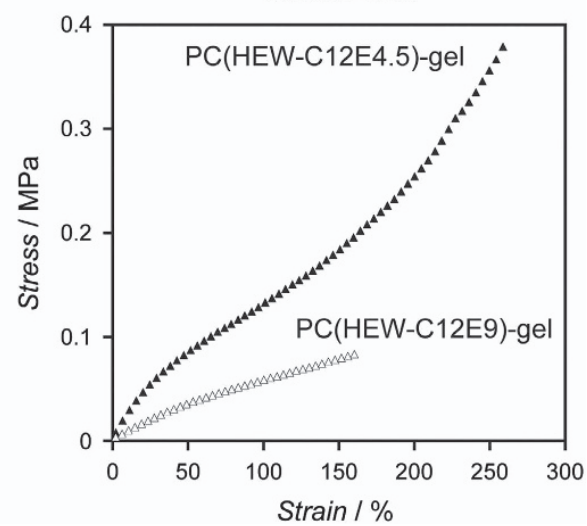

Figure 2 Thermal gelation of $\mathrm{PC}(\mathrm{HEW})$ and its mechanical strength. (a) Fluidic $\mathrm{PC}(\mathrm{HEW})$ was gelled by heating at $70^{\circ} \mathrm{C}$. (b) Compressive stress-strain curve of PC(HEW)-gels. Inset: stress-strain curve of boiled egg white. (c) Tensile stress-strain curve of PC(HEW)-gels. 
the SAXS profile of egg white, indicating that various proteins, such as OVA, OVT and LYS, were packed inside the PC with an ordered structure. Consistent with the higher protein content of PC(HEW $\mathrm{C}_{12} \mathrm{E}_{4.5}$ ), the protein-protein correlation distance calculated from the scattering peak position $(d=2 \pi / Q)$ of $\mathrm{PC}\left(\mathrm{HEW}-\mathrm{C}_{12} \mathrm{E}_{4.5}\right)$ $\left(Q=0.743 \mathrm{~nm}^{-1}, d=8.45 \mathrm{~nm}\right)$ was shorter than that of PC(HEW $\left.\mathrm{C}_{12} \mathrm{E}_{9}\right)\left(\mathrm{Q}=0.718 \mathrm{~nm}^{-1}, d=8.75 \mathrm{~nm}\right)$, revealing the closer packing of proteins.

Similar to the HEW protein solution, ${ }^{10} \mathrm{PC}(\mathrm{HEW})$ became a white opaque gel by heating at $70^{\circ} \mathrm{C}$ for $20 \mathrm{~min}$ (Figure 2a). The PC $\left(\mathrm{HEW}-\mathrm{C}_{12} \mathrm{E}_{9}\right)$-gel and $\mathrm{PC}\left(\mathrm{HEW}-\mathrm{C}_{12} \mathrm{E}_{4.5}\right)$-gel retained $82 \%$ and $76 \%(w / w)$ water, respectively (Supplementary Figure S1). PCs were dissolved in an $\mathrm{NaCl}$ solution, which disrupts the electrostatic interactions between proteins and surfactants. ${ }^{9}$ The PC(HEW)-gel was stable in the $\mathrm{NaCl}$ solution and was degraded by protease (Supplementary Figure S2). $\mathrm{NaCl}$ stability and protease degradability indicated that the network structure of PC(HEW)-gel was constructed by polypeptide chains.

The mechanical strengths of $\mathrm{PC}(\mathrm{HEW})$-gels are summarized in Figures $2 \mathrm{~b}$ and $\mathrm{c}$ and Table 1 . To prepare samples for measurement, $\mathrm{PC}(\mathrm{HEW})$ was poured into a mold and heated (Supplementary Figure S3). Figure $2 \mathrm{~b}$ shows the compressive stress-strain curves of the PC(HEW $\left.-\mathrm{C}_{12} \mathrm{E}_{9}\right)$-gel and $\mathrm{PC}\left(\mathrm{HEW}-\mathrm{C}_{12} \mathrm{E}_{4.5}\right)$-gel, with a stress of 2.9 $\mathrm{MPa}$ and $34.5 \mathrm{MPa}$, respectively. The fracture strength for $\mathrm{PC}$ (HEW- $\mathrm{C}_{12} \mathrm{E}_{4.5}$ )-gel was 150 -fold higher than that for boiled egg white $(-0.2 \mathrm{MPa} \text {; Figure } 2 \mathrm{~b} \text {, inset })^{11}$ and was comparable to that of synthesized high-strength hydrogels., ${ }^{72}$ The 11-fold higher strength of the $\mathrm{PC}\left(\mathrm{HEW}-\mathrm{C}_{12} \mathrm{E}_{4.5}\right)$-gel compared to the $\mathrm{PC}\left(\mathrm{HEW}-\mathrm{C}_{12} \mathrm{E}_{9}\right)$-gel would be due to the higher protein content with appropriate ordered arrangement of proteins in $\mathrm{PC}\left(\mathrm{HEW}-\mathrm{C}_{12} \mathrm{E}_{4.5}\right)$. As shown in tensile testing (Figure 2c), $\mathrm{PC}\left(\mathrm{HEW}-\mathrm{C}_{12} \mathrm{E}_{4.5}\right.$ )-gel showed a fracture strain of $260 \%$. This result revealed the elastic property of the PC(HEW$\mathrm{C}_{12} \mathrm{E}_{4.5}$ )-gel, which contrasts with the typical nature of boiled egg white. The $\mathrm{PC}\left(\mathrm{HEW}-\mathrm{C}_{12} \mathrm{E}_{4.5}\right)$-gel showed a higher compressive and tensile elastic modulus than the $\mathrm{PC}\left(\mathrm{HEW}-\mathrm{C}_{12} \mathrm{E}_{9}\right)$-gel, indicating a higher network density of the $\mathrm{PC}\left(\mathrm{HEW}-\mathrm{C}_{12} \mathrm{E}_{4.5}\right)$-gel.

OVA is the most abundant protein in HEW making up over half of the total protein content of egg white and is the dominant factor for the gelation property of egg white. ${ }^{13}$ We investigated whether OVA, the main protein in $\mathrm{PC}(\mathrm{HEW})$, also promotes the heat-induced gelation of $\mathrm{PC}(\mathrm{HEW})$. In our previous study, we demonstrated PC formation from purified OVA and LYS ${ }^{9}$ (Supplementary Materials and Supplementary Table S1). Here, we tested the thermal gelation property of both PCs (Supplementary Materials and Supplementary Figure S4). Although the PC of LYS did not form a gel on heating at $70^{\circ} \mathrm{C}$, the PC of OVA became an opaque gel with high mechanical strength, comparable to that of the PC(HEW)-gel. We concluded that the thermal gelation property of $\mathrm{PC}(\mathrm{HEW})$ and the high mechanical strength of the gel resulted from the network structure constructed by OVA.

OVA contains four free $\mathrm{SH}$ groups that are buried in the native structure. ${ }^{14}$ When OVA is heat denatured, the SH groups are exposed and disulfide bonds form between denatured proteins. ${ }^{15}$ The contributions of covalent disulfide bonds and non-covalent interactions for the construction of the $\mathrm{PC}(\mathrm{HEW})$-gel network were separately revealed (Figure 3).

Iodoacetamide (IAA) covalently modifies the $\mathrm{SH}$ group of cysteine residues and prevents the formation of disulfide bonds (Figure 3a). ${ }^{16}$ $\mathrm{PC}\left(\mathrm{HEW}-\mathrm{C}_{12} \mathrm{E}_{4.5}\right)$ was prepared in the presence of IAA. Although disulfide bond formation was prevented, IAA-treated PC(HEW$\mathrm{C}_{12} \mathrm{E}_{4.5}$ ) formed an opaque gel by heating on $70^{\circ} \mathrm{C}$. This result shows 
a

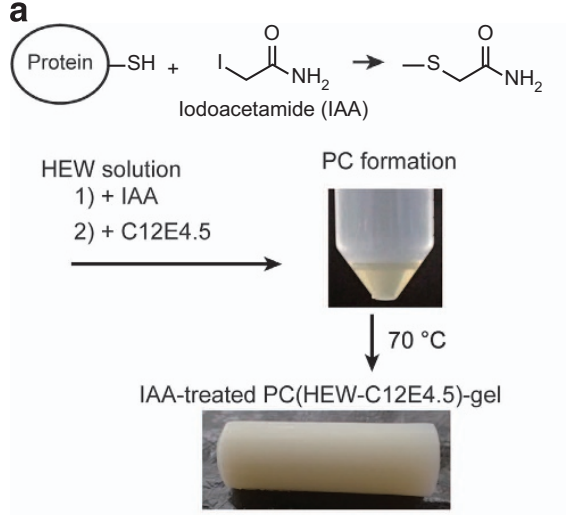

c

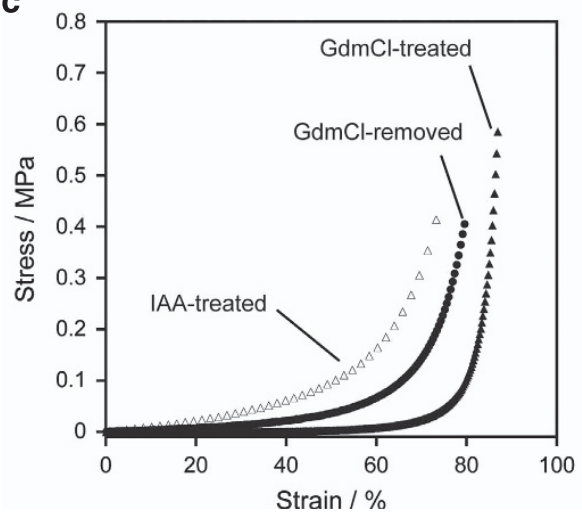

b

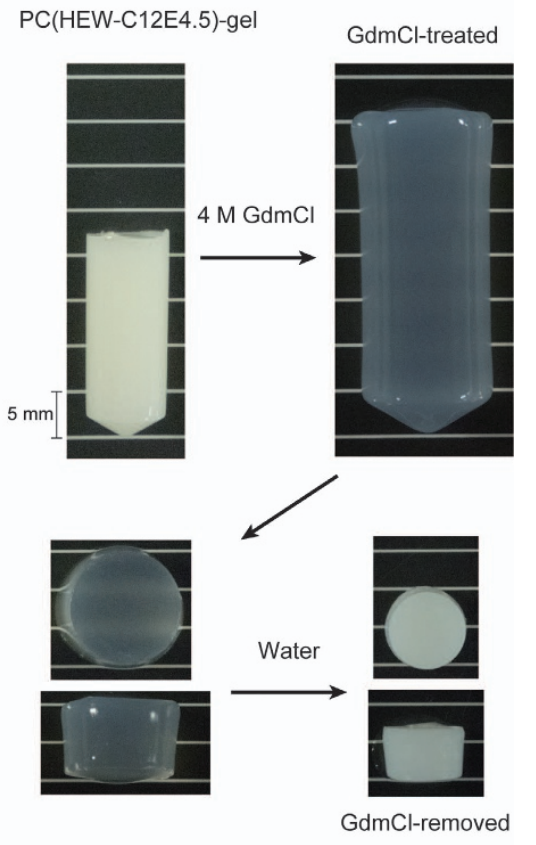

Figure 3 Non-covalent network and covalent disulfide bond network coexist in PC(HEW)-gel. (a) IAA prevents disulfide bond formation. HEW proteins formed $\mathrm{PC}$ by the addition of the $\mathrm{C}_{12} \mathrm{E}_{4.5}$ surfactant in the presence of $80 \mathrm{~mm}$ IAA. IAA-treated PC was gelled by heating at $70{ }^{\circ} \mathrm{C}$. (b) The PC( $\left.\mathrm{HEW}-\mathrm{C}_{12} \mathrm{E}_{4.5}\right)$-gel swelled and became semitransparent when kept in $4 \mathrm{~m} \mathrm{GdmCl}$ for $144 \mathrm{~h}$. The $\mathrm{GdmCl}$-treated PC(HEW- $\left.\mathrm{C}_{12} \mathrm{E}_{4.5}\right)$-gel was sliced and incubated in water to remove $\mathrm{GdmCl}$ for $24 \mathrm{~h}$. The gel regained a white opaque appearance ( $\mathrm{GdmCl}$ removed). (c) Compressive stress-strain curve of IAA-treated, GdmCl-treated, and $\mathrm{GdmCl}$-removed PC(HEW $\left.-\mathrm{C}_{12} \mathrm{E}_{4.5}\right)$-gel.

that heat-denatured proteins inside PC formed a network structure via non-covalent interactions during the gelation process.

The protein denaturant reagent guanidinium chloride $(\mathrm{GdmCl})$ solubilizes non-covalent protein associations and improves the water solubility of denatured proteins. The $\mathrm{PC}\left(\mathrm{HEW}-\mathrm{C}_{12} \mathrm{E}_{4.5}\right)$-gel was immersed in $4 \mathrm{M} \mathrm{GdmCl}$ (Figure $3 \mathrm{~b}$ ). The gel swelled, maintaining its overall structure, and became semitransparent due to the solubilization of the large structures of non-covalently associated polypeptide chains and the extension of polypeptide chains in the $\mathrm{GdmCl}$ solution. ${ }^{17}$ Treatment of the $\mathrm{PC}\left(\mathrm{HEW}-\mathrm{C}_{12} \mathrm{E}_{4.5}\right)$-gel with $6 \mathrm{M}$ urea and $2 \%(\mathrm{w} / \mathrm{v})$ sodium dodecyl sulfate (SDS) showed similar results (Supplementary Figure S5a). The swollen gel was dissolved by addition of dithiothreitol, which is a reducing reagent used for the cleavage of disulfide bonds (Supplementary Figure S5a). These results showed that the covalent network structure was constructed by disulfide bonds between denatured proteins.

Interestingly, both IAA and GdmCl-treated $\mathrm{PC}\left(\mathrm{HEW}-\mathrm{C}_{12} \mathrm{E}_{4.5}\right)$ gels showed drastically weakened compressive strengths of 0.43 and $0.59 \mathrm{MPa}$, respectively (Figure $3 \mathrm{c}$ ). This result indicate that the high mechanical strength of the $\mathrm{PC}(\mathrm{HEW})$-gel can be attributed to the synergic non-linear effects of non-covalent and covalent networks with different properties. The synergic effects of the combination of two independent polymer networks with different properties for improved mechanical strength has been described as a DN (double network) gel. ${ }^{10}$ In our PC(HEW)-gel, the two networks were not independent because different regions within single denatured proteins mediated the formation of non-covalent and covalent networks. We investigated the effect of the arrangement of both networks. After immersion of the GdmCl-treated PC(HEW $\left.-\mathrm{C}_{12} \mathrm{E}_{4.5}\right)$-gel in water, the gel shrank and regained a white opaque appearance, indicating regeneration of the non-covalent network (Figure 3c). However, synergic effects were not observed and the gel showed a weak compressive strength of $0.42 \mathrm{MPa}$. We concluded that the non-covalent and covalent networks should be formed from the spatially confined PC state to construct ordered and orchestrated network structures with high mechanical strength.

The heat-induced gelation of egg white and its fragility are common knowledge. Our results open up new possibilities for egg white proteins as a resource for the development of materials. The method is simple and effective, and could be applied to other proteins together with protein engineering technology (for example, introduction of cysteine residues for covalent network formation) for the development of a new class of functional soluble globular protein-based materials.

\section{CONFLICT OF INTEREST}

The authors declare no conflict of interest.

\section{ACKNOWLEDGEMENTS}

This work was supported by JST ERATO Iyoda Supra-Integrated Material Project, Grant Number JPMJER1001 and Kieikai Research Foundation. The authors acknowledge Dr M. Sugiyama (Kyoto University) and Dr R. Inoue (Kyoto University) for support with SAXS measurement; Dr A. Shishido (Tokyo Institute of Technology) for support with tensile strength measurement; 
Dr T. Miyata (Kansai University) and C. Norioka (Kansai University) for support with compressive strength measurement; and Dr H. Taguchi (Tokyo Institute of Technology) for support with lab equipment.

\section{PUBLISHER'S NOTE}

Springer Nature remains neutral with regard to jurisdictional claims in published maps and institutional affiliations.

$1 \mathrm{Hu}$, X., Cebe, P., Weiss, A. S., Omenetto, F. \& Kaplan, D. L. Protein-based composite materials. Mater. Today 15, 208-215 (2012).

2 Nojima, T., Suzuki, S. \& lyoda, T. Atelocollagen-templated fabrication of tangled fibrous silica. J. Mater. Chem. B 4, 6640-6643 (2016).

3 Numata, K., Ifuku, N., Masunaga, H., Hikima, T. \& Sakai, T. Silk resin with hydrated dual chemical-physical cross-links achieves high strength and toughness. Biomacromolecules 18, 1937-1946 (2017).

4 Campbell, L., Raikos, V. \& Euston, S. R. Modification of functional properties of eggwhite proteins. Nahrung 47, 369-376 (2003).

5 Sun, Y. X. \& Hayakawa, S. Heat-induced gels of egg white/ovalbumins from five avian species: thermal aggregation, molecular forces involved, and rheological properties. $J$. Agr. Food Chem. 50, 1636-1642 (2002).

6 Van der Plancken, I., Van Loey, A. \& Hendrickx, M. E. G. Changes in sulfhydryl content of egg white proteins due to heat and pressure treatment. J. Agr. Food Chem. 53, 5726-5733 (2005)

7 Sakai, T., Matsunaga, T., Yamamoto, Y., Ito, C., Yoshida, R., Suzuki, S., Sasaki, N., Shibayama, M. \& Chung, U. Design and fabrication of a high-strength hydrogel with ideally homogeneous network structure from tetrahedron-like macromonomers. Macromolecules 41, 5379-5384 (2008)

8 Matsunaga, T., Sakai, T., Akagi, Y., Chung, U. \& Shibayama, M. Structure characterization of tetra-PEG gel by small-angle neutron scattering. Macromolecules 42, 1344-1351 (2009).

9 Nojima, T. \& lyoda, T. Water-rich fluid material containing orderly condensed proteins. Angew. Chem. Int. Edit 56, 1308-1312 (2017).
10 Iwashita, K., Inoue, N., Handa, A. \& Shiraki, K. Thermal aggregation of hen egg white proteins in the presence of salts. Protein J. 34, 212-219 (2015)

11 Hsieh, Y. L. \& Regenstein, J. M. Failure deformation and stress-relaxation of heated egg-white gels. J. Food Sci. 58, 113-115 (1993).

12 Gong, J. P., Katsuyama, Y., Kurokawa, T. \& Osada, Y. Double-network hydrogels with extremely high mechanical strength. Adv. Mater. 15, 1155-1158 (2003).

13 Iwashita, K., Handa, A. \& Shiraki, K. Co-aggregation of ovalbumin and lysozyme. Food Hydrocolloid 67, 206-215 (2017).

14 Huntington, J. A. \& Stein, P. E. Structure and properties of ovalbumin. J. Chromatogr. B 756, 189-198 (2001).

15 Rumbo, M., Chirdo, F. G., Fossati, C. A. \& Anon, M. C. Analysis of structural properties and immunochemical reactivity of heat-treated ovalbumin. J. Agr. Food Chem. 44, 3793-3798 (1996).

16 Anson, M. L. The reactions of iodine and iodoacetamide with native egg albumin. J. Gen. Physiol. 23, 321-331 (1940).

17 Kohn, J. E., Millet, I. S., Jacob, J., Zagrovic, B., Dillon, T. M., Cingel, N., Dothager, R. S., Seifert, S., Thiyagarajan, P., Sosnick, T. R., Hasan, M. Z., Pande, V. S., Ruczinski, I., Doniach, S. \& Plaxco, K. W. Random-coil behavior and the dimensions of chemically unfolded proteins. Proc. Natl Acad. Sci. USA 101, 12491-12496 (2004).

(i) This work is licensed under a Creative Commons Attribution 4.0 International License. The images or other third party material in this article are included in the article's Creative Commons license, unless indicated otherwise in the credit line; if the material is not included under the Creative Commons license, users will need to obtain permission from the license holder to reproduce the material. To view a copy of this license, visit http:// creativecommons.org/licenses/by/4.0/

(C) The Author(s) 2018

Supplementary Information accompanies the paper on the NPG Asia Materials website (http://www.nature.com/am) 